\title{
IAMJ
}

INTERNATIONAL

AYURVEDIC

MEDICAL JOURNAL

\section{A COMPARATIVE CLINICAL STUDY OF PANCHAPALAKA GHRITA AND DHANYAKA GHRITA IN UDAVARTINI YONIVYAPAD}

\author{
Sruthi K ${ }^{1}$, Kavitha B. K. ${ }^{2}$ \\ ${ }^{1} 3^{\text {rd }}$ year PG Scholar, ${ }^{2}$ Associate Professor, \\ Dept of Prasooti Tantra Evum Stree Roga, Alva's Ayurveda Medical College Moodbidri, Dakshin Kannada, \\ Karnataka, India
}

\section{Corresponding Author: sruthikodoth23@gmail.com}

\section{https://doi.org/10.46607/iamj06p4052020}

(Published online: July 2020)

Open Access

(C) International Ayurvedic Medical Journal, India 2020

Article Received: 08/06/2020 - Peer Reviewed: 23/08/2020 - Accepted for Publication: 23/08/2020

Check for updates

\section{ABSTRACT}

Background and Objectives: Menstrual cycle is the natural regular change occur in the female reproductive system. Menstruation is often associated with problems of irregular menstruation, disorders in menstrual bleeding and dysmenorrhoea, among which dysmenorrhoea is the most common gynecological problem. Dysmenorrhoea is painful cramps of uterine origin. If it is severe it causes high impact on women's life. It leads to restriction in daily activities, a lower academic performance in adolescents, and poor quality of sleep and has negative effects on mood causing anxiety and depression.

In Ayurveda 20 types of Yoni Vyapada are described out of which Udavartini is one which is characterized by painful menstruation and can be correlated with primary dysmenorrhoea.

Objectives: To evaluate and compare the efficacy of Panchapalaka Ghrita and Dhanyaka Ghrita in the management of Udavartini Yonivyapad.

Methodology: This research work was a randomized comparative clinical study of 40 patients suffering from cardinal symptoms of Udavartini, were randomly selected and categorized into 2 groups of 20 patient each. Group A was treated with Panchapalaka Ghrita and group B with Dhanyaka Ghrita. Both Ghritas were given in Apanakaala (before food) with Sukhoshna Jala as Anupana.

Duration of Treatment- 10 days (Starting 7days before commencement of cycle till $3^{\text {rd }}$ day of menstrual cycle) for 3 consecutive cycle. 
Results and Interpretation- Both the groups showed statistically significant results. Statistically there was no significant difference between the groups

Conclusion: Both Panchapalaka Ghrita and Dhanyaka Ghrita has equal effect in Udavartini Yonivyapad.

Keywords: Udavartini, Dysmenorrhea, Panchapalaka Ghrita, Dhanyaka Ghrita.

\section{INTRODUCTION}

Menstrual problems such as dysmenorrhoea, irregular menstrual cycles, irregular bleeding are common gynecological complaints among adolescent girls which creates physical and psychological disturbances in day-today life. Dysmenorrhoea is common and in up to $20 \%$ of women, it may be severe enough to interfere with day-to-day activities ${ }^{1}$.

Dysmenorrhoea is defined as painful menstruation of sufficient magnitude to incapacitate day-to-day activities. It is divided into Primary dysmenorrhoea and Secondary dysmenorrhoea. The Primary dysmenorrhoea is one where there is no pelvic pathology, and Secondary dysmenorrhoea is considered menstruation-associated pain occurring in the presence of pelvic pathology ${ }^{2}$.

The prevalence of dysmenorrhea is most common in women between the ages of 16- 25 years. About $80 \%$ of the women develop dysmenorrhea within 3years of menarche.

According to Ayurvedic classics, a number of gynecological problems are described under the heading of Yonivyapad. Primary dysmenorrhoea can be correlated with Udavartini Yonivyapad, which is characterized by painful menstruation ${ }^{3}$. For all Yoni Vikaras vitiated $A p$ ana Vayu is considered as primary cause. Apana Vata does Artava nishkramana kriya, so painful menstruation is considered as Apanavata Dushti ${ }^{4}$.

In Udavartini Yonivyapad due to Swaprakopaka Nidanas like Vegadharana and Vataprakopaka Ahara Vihara causes Pratiloma Gati of Apana Vata leading to Raja Krichrata. Both Panchapalaka Ghrita and Dhanyaka Ghrita are Yogas, which contains drugs having Vata Anulomana, Dipana, Pachana, Balya and Shoolahara properties.

Keeping this into consideration and as per treatment principles of Udavartini study has done to compare the effect of Panchapalaka Ghrita and Dhanyaka Ghrita ${ }^{6}$ in the management of Udavartini Yonivyapad.

\section{Materials and Methods:}

Collection of Sources: 40 samples were selected randomly from OPD of PTSR dept of Alva's Ayurveda Hospital, Moodbidri, Medical camps and other referrals, irrespective of their religion, economic status \& occupation.

Study design: A randomized comparative clinical study

Collection and preparation of Drug: Raw drugs were identified and collected from local market and Ghrita was prepared at Alvas RSBK laboratory

For Panchapalaka Ghrita:

- Kalka dravyas - Sunti, Pippalimoola, Dadima, Dhanyaka.

- Sneha Dravya - Ghrita

- Drava Dravya - Ksheera.

For Dhanyaka Ghrita:

- Kalka Dravya - Jeeraka

- Sneha Dravya - Ghrita

- Drava Dravya - Dhanyaka Kashaya.

Panchapalaka Ghrita and Dhanyaka Ghrita were prepared in Mandagni according to Ghritapaaka Vidhi of Bhaishajya Kalpana till attaining Sneha Siddha Lakshana.

\section{Anupana - Sukoshna Jala \\ Diagnostic Criteria}

Patients fulfilling any of the following diagnostic criteria were selected for the study, irrespective of associated symptoms.

1. Painful menstruation which begins one or two days before menstruation or with onset of menstruation and lasting for few hours or 1 to 2 days.

2. Painful menstruation along with pain in the lower abdomen and low back area which is radiating to the medial aspects of thighs. 
3. Painful menstruation associated with any of the symptoms such as headache, nausea, vomiting, irritability, diarrhea, fatigue, giddiness.

\section{Inclusion Criteria:}

1) Patients fulfilling the diagnostic criteria.

2) Age between 16-30 years.

3) Married and unmarried.

4) $\mathrm{H} / \mathrm{O}$ Painful menstruation for at least 3 consecutive cycles

5) Patients with regular menstrual cycles.

\section{Exclusion Criteria:}

1) Cases of Secondary dysmenorrhea with pelvic pathology like Fibroid Uterus, Ovarian Cyst, Endometriosis, Adenomyosis, Pelvic inflammatory diseases, Cervicitis.

2) Patient on hormonal therapy, contraception and IUCD.

3) Patients having any systemic diseases like Diabetes Mellitus, Hypertension

4) Endocrinal disorders like Thyroid abnormalities, PCOD.

\section{Drug Intervention:}

The patients fulfilling the criteria for inclusion were randomly assigned into 2 groups $\mathrm{A}$ and $\mathrm{B}$, each comprising of 20 patients:

\begin{tabular}{|l|l|l|l|l|l|}
\hline Group & No. of volunteers & Yoga & Dose & Time of administration & Anupana \\
\hline A & 20 & Panchapalaka Ghrita & $15 \mathrm{ml} \mathrm{BD}$ & Before food & Sukhoshna Jala \\
\hline B & 20 & Dhanyaka Ghrita & $15 \mathrm{ml} \mathrm{BD}$ & Before food & Sukhoshna Jala \\
\hline
\end{tabular}

Duration of Treatment: 10 days (starting 7 days before commencement of menstrual cycle till $3^{\text {rd }}$ day of menstruation) for 3 consecutive cycle.

Total duration of treatment: 3 months

Assessment: Done on $3^{\text {rd }}$ day of each menstrual cycle for 3 Consecutive cycles

Follow up: After 1 month of treatment

Assessment Criteria:

a) Intensity of pain

b) Duration of pain c) Site of pain - Lower abdomen, Low back, Pain radiating to thigh

d) Relief in associated symptoms - Vomiting, Diarrhea, Irritability, Constipation, Nausea, Headache, Breast tenderness

- Pain criteria was assessed using VAS and FLA grading and scoring system.

- These parameters were graded, and scores given accordingly.

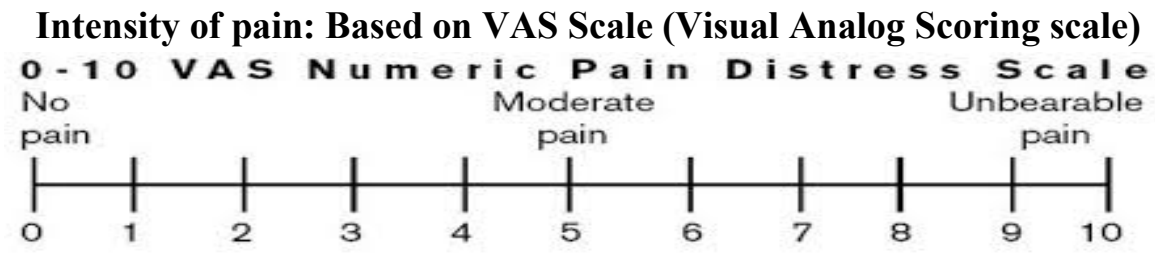
1. No Pain -0
- Grade - 0
2. Mild pain $-1-3$
- Grade - 1
3. Moderate pain - 4-6 - Grade - 2
4. Severe pain $-7-10 \quad-$ Grade -3

FLA Scale

Each of 3 categories F (face), L(leg) and A(activity) is scored from 0-2.

This results in a total score of $0-9$

\section{FLA grading system}

\begin{tabular}{|l|l|l|l|}
\hline Categories & $\mathbf{0}$ & $\mathbf{1}$ & $\mathbf{2}$ \\
\hline Face & No particular expression & Distressed appearance Wrinkled Brow & Fearful expression, clenched jaw \\
\hline Leg & Normal position, or relaxed & Uneasy restless Tense & Legs drown up \\
\hline Activity & Normal position moves easily & Shifting back\& forth, tense & Arched, rigid or jerking or rubbing body parts \\
\hline
\end{tabular}




\begin{tabular}{|c|c|c|c|c|}
\hline Assessment Criteria & Grade 0 & Grade 1 & Grade 2 & Grade 3 \\
\hline 1. Intensity of pain & $\begin{array}{l}\text { 0 (No pain) } \\
\text { Menstruation } \\
\text { is not painful } \\
\text { and daily activ- } \\
\text { ity is unaf- } \\
\text { fected. }\end{array}$ & $\begin{array}{l}\mathbf{1} \text { to } 3 \text { (Mild pain) } \\
\text { Menstruation is painful } \\
\text { but daily activity is not } \\
\text { affected. }\end{array}$ & $\begin{array}{l}4 \text { to } 6 \text { (Moderate pain) } \\
\text { Menstruation is pain- } \\
\text { ful and daily activity } \\
\text { is affected. } \\
\text { Analgesic drug is } \\
\text { needed. }\end{array}$ & $\begin{array}{l}7 \text { to } 10 \text { (Severe pain) } \\
\text { Menstruation is so painful } \\
\text { that patient is unable to do } \\
\text { even the routine work and } \\
\text { has to take analgesic, but not } \\
\text { much relief. }\end{array}$ \\
\hline 2. Duration of Pain & No pain & $\begin{array}{l}\text { Pain continues for up-to } \\
24 \mathrm{hrs} \text {. }\end{array}$ & $\begin{array}{l}\text { Pain continues for } 24 \\
\text { to }<48 \mathrm{hrs}\end{array}$ & $\begin{array}{l}\text { Pain continues for } 48 \text { hours } \\
\text { to }<72 \mathrm{hrs}\end{array}$ \\
\hline $\begin{array}{l}\text { 3. Site of pain } \\
\text { (Lower Abdomen } \\
\text { pain, } \\
\text { Back pain, Pain } \\
\text { radiating to thighs) }\end{array}$ & No pain & $\begin{array}{l}\text { Presence of all } 3 \text { for less } \\
\text { than } 1 \mathrm{~h} / \text { any two fea- } \\
\text { tures for less than } 6 \mathrm{~h} / \\
\text { any one feature for less } \\
\text { than } 12 \mathrm{~h}\end{array}$ & $\begin{array}{l}\text { Presence of all } 3 \text { for } 1- \\
2 \mathrm{~h} / \text { any two features } \\
\text { for } 6-12 \mathrm{~h} / \text { any one } \\
\text { feature for more than } \\
12 \mathrm{~h}\end{array}$ & $\begin{array}{l}\text { Presence of all } 3 \text { for more } \\
\text { than } 2 \mathrm{~h} / \text { any two features for } \\
12-24 \mathrm{~h} / \text { any one feature for } \\
24 \mathrm{~h}\end{array}$ \\
\hline $\begin{array}{l}\text { 4.Associated com- } \\
\text { plaints } \\
\text { (nausea, vomiting, di- } \\
\text { arrhea, headache, irri- } \\
\text { tability, constipation, } \\
\text { breast tenderness) }\end{array}$ & $\begin{array}{l}\text { No associated } \\
\text { complaints }\end{array}$ & $1-3$ complaints & 4-6 complaints & More than 6 complaints \\
\hline
\end{tabular}

\section{Overall Assessment:}

The total effect of the therapy was assessed considering the overall improvement in signs and symptoms.

$>$ Marked Improvement: $76 \%-100 \%$ relief in the signs and symptoms

$>$ Moderate Improvement: $51 \%-75 \%$ relief in the signs and symptoms

$>$ Mild Improvement: $26 \%-50 \%$ relief in the signs and symptoms
$>$ Unchanged: Below 25\% relief in the signs and symptoms

Statistical Analysis: The obtained data was analyzed statistically using Unpaired ' $t$ ' test where conceded at the level of $p<0.001$ as highly significant, $p<0.05$ or $\mathrm{p}<0.01$ as significant and $\mathrm{p}>0.01$ as insignificant to carry out the results.

\section{Assessment of Total Effect of Therapy}

\section{Comparative results of Group A and Group B}

\begin{tabular}{|c|c|c|c|c|c|c|c|}
\hline \multirow[t]{2}{*}{ Parameters } & \multicolumn{2}{|c|}{ BT-AT Mean } & \multirow[b]{2}{*}{$\mathrm{d}$} & \multicolumn{2}{|c|}{$\%$ of relief } & \multirow[t]{2}{*}{$\mathrm{t}$ value } & \multirow[t]{2}{*}{ P value } \\
\hline & Group A & Group B & & Group A & Group B & & \\
\hline Intensity of pain & 1.0 & 1.2 & -0.2 & 51.28 & 53.33 & -1.165 & 0.251 \\
\hline Duration of pain & 1.20 & 1.35 & -0.15 & 63.15 & 60 & -0.936 & 0.355 \\
\hline Site of pain & 1.2 & 1.15 & 0.05 & 64.86 & 56.09 & 0.263 & 0.794 \\
\hline \multirow[t]{2}{*}{ Associated complaints } & 0.9 & 1.5 & -0.6 & 64.28 & 65.21 & -3.269 & 0.002 \\
\hline & & & & 60.89 & 58.65 & & \\
\hline
\end{tabular}




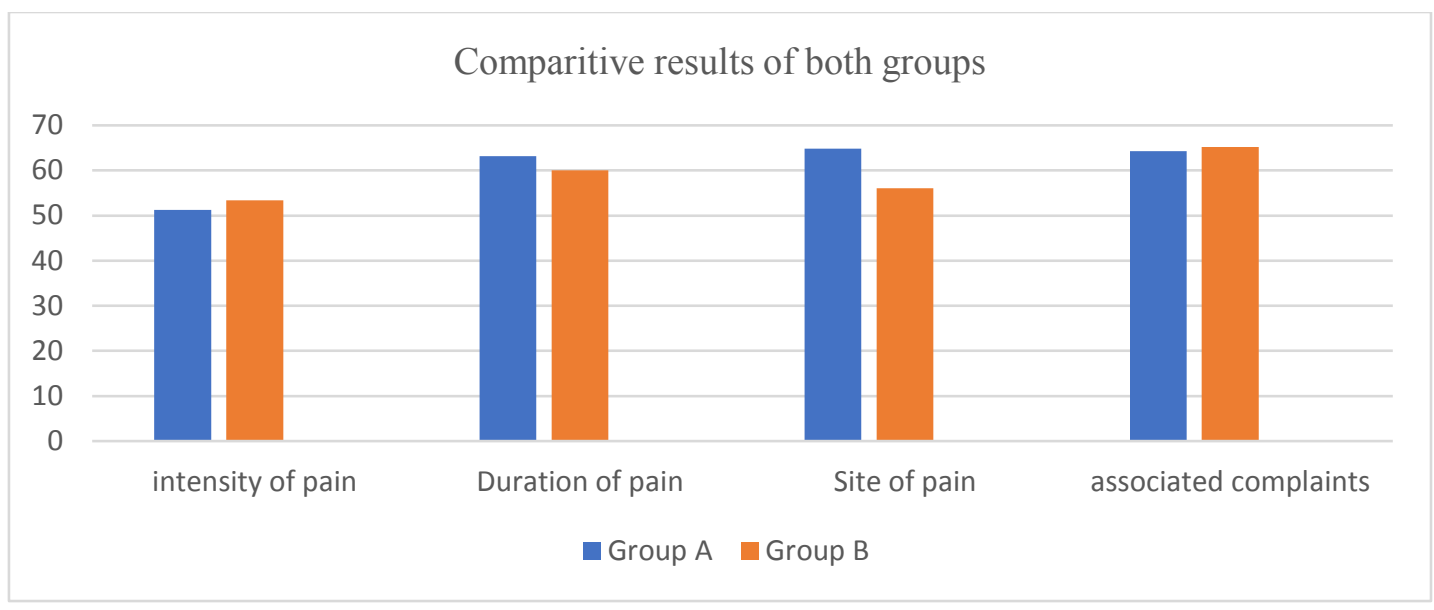

Comparative results of Group A and Group B

Overall effect of Treatment in Group-A and Group B

\begin{tabular}{|l|l|l|l|l|l|}
\hline \multicolumn{2}{|l|}{} & Group A & Group B \\
\hline Class & Grading & No. of Patients & Percentage & No. of Patients & Percentage \\
\hline$<25 \%$ & No improvement & 0 & $0 \%$ & 0 & $0 \%$ \\
\hline $26-50 \%$ & Mild Improvement & 6 & $30 \%$ & 5 & $25 \%$ \\
\hline $51-75 \%$ & Moderate Improvement & 8 & $40 \%$ & 7 & $35 \%$ \\
\hline $76-100 \%$ & Marked Improvement & 6 & $30 \%$ & 8 & $40 \%$ \\
\hline
\end{tabular}

\section{DISCUSSION}

- If Apana Vata is got Avarana by Vyana that can result in causing Margavarodha that, hinder the normal flow of menses, which can result in pain.

- Kapha Vardaka Ahara Vihara result in Agnimandya and Amotpatti which cause Upalepa to Artavavaha Srotas creating Avaroda to Gati of Apana Vata which will also result in painful menstruation.

- In Udavartini Yonivyapad due to Swaprakopaka Nidanas like Mootra Vegadharana and Vataprakopaka Ahara Vihara causes Pratiloma Gati of Apana Vata leading to Raja Krichrata.

Probable Mode of Action of Panchapalaka Ghrita Panchapalaka Ghrita is a formulation mentioned as Yoni shoolanashaka and Vata Gulmahara by Chakrapanidatta in Chakradattaa, under Gulmaroga chikitsaprakaranam and contains Pippali, Dadima, Dhanyaka, Shunti, Go Ghrita and Go Ksheera.

Based on Rasa: Katu, Tikta, Kasaya and Madhura Rasas

- Katu and Tikta Rasa Pradhana, having Dipana properties. By its Sukshma Guna, it can pierce all the minute channels thus Garbhashaya Shudhikara. Tikta Rasa is Kapha Shoshaka and remove the Avarana in Artava Vaha Srotas. It increases appetite, digestion and reduces nausea and vomiting. Based on Guna: Laghu, Snigda, Ruksha, Sukshma Gunas - It is Tridoshagna, and is Sroto Shodhana and Shigrapaaki.

Based on Veerya: Ushna

- Due to Ushna Guna it acts as vasodilatation and thus the menstrual blood flows more easily along with Vatanulomana.

Based on Vipaka: Madhura, Amla

- It acts as Vata Samaka and thereby controls Apana Vayu.

\section{Based on Karma:}

- It has Srotoshodhana action thus it enhances the drug penetration and better absorption.

- Due to its Dipana and Pachana effect it acts as Amapachana, it corrects the Agni of patient.

- Vedanastapaka, Ruchya and Hridya properties of drugs give relief from menstrual pain and associated complaints. 


\section{Probable Mode of Action of Dhanyaka Ghrita}

Dhanyaka Ghrita indicated in Yonishoola, Gudashoola, Amashoola, it is Agnideepana and Hrdya, mentioned in Ajirnadhikara of Vangasena. It contains Dhanyaka, Jeeraka and Ghrita as ingredients having properties like Vata Shamaka and Vatanulomana.

Based on Rasa, Virya and Vipaka- Katu, Tikta Rasa, Laghu, Ruksha, Sukshma Guna, Ushna Veerya, Katu and Madhura Vipaka

- Katu Rasa act as Agnideepana and Laghu Guna helps to pacify vitiated Kapha. Ushna Veerya removes Avarana and allows normal Gati of Vata.

- By Snigdha Guna and Madhura Vipaka pacifies vitiated Vata.

- Tikta Rasa has Agni Vardhaka, Ruchya and Mukha Shodhaka properties. Therefore, it increases appetite and improves digestion.
- Hridya action helps in reliving irritability and reduces nausea and vomiting.

- It has Vrushya action, which prepares female reproductive system for healthy ovulation and conception in upcoming Rithukala.

\section{Based on Karma:}

- Jeeraka act as Garbhahaya Shodhakara and Shoolaprashamana, action cures Rajah Krichrata of Udavartini. Vatanulomana brings normal Gati of Vikrita Apanavata

- Jeeraka by its Deepana, Pachana, Rochana action helps in preventing agnimandya. Kaphagna action helps to remove Ama and removes Sanga caused to Gati of Vayu.

\section{Discussion on Result}

\begin{tabular}{|l|l|l|l|}
\hline PARAMETERS & \% of relief & P Value \\
\hline & Group A & Group B & \\
\hline Intensity of pain & 51.28 & 53.33 & 0.251 (Insignificant) \\
\hline Duration of pain & 63.15 & 60 & 0.355 (Insignificant) \\
\hline Site of pain & 64.86 & 56.09 & 0.794 (Insignificant) \\
\hline Associated complaints & 64.28 & 65.21 & 0.002 (Significant) \\
\hline Overall \% & 60.89 & 58.65 & \\
\hline
\end{tabular}

- Ghrita itself has properties such as Udavartaprasamana, Shoolaprasamana, Vata-Pitta Prasamana, Agni deepana ${ }^{7}$ properties which will be helping in the reduction of Udavartini

\section{In Duration and site of pain - Panchapalaka Ghrita} showed more result

- Pippali act as Shoolaprasamana and has antispasmodic action. Dadima is Hridya, Raktadustihara, and Tridoshahara and is a potent relaxant. Shunti has Shoolaprasamana and Vatanulomana properties. Dhanyaka act as Agnideepana, Vata-Kaphanulomana and its Ushna Veerya removes Avarana and allows normal Gati of Vata.

- Ksheera is Madhura, Snigda, Vata-Pitta Hara and is Jeevana, Brimhana, Balya and Rasayana. Mridhuvirechana Karma does Anulomana of Apana Vata. Ghrita is Udavartahara
In Intensity and associated complaints - Dhanyaka Ghrita showed more result

- Jeeraka is Garbhahaya Shodhakara and Shoolaprashamana, which cures Raja Krichrata of Udavartini. Vatanulomana brings normal Gati of Vikrita Apanavata.

- Katu Rasa, Ushna Veerya and Katu Vipaka of Jeeraka act as Agnideepana, and Balya.

- Jeeraka is mentioned under Shoolaprasamana Gana by Charaka indicates the pain-relieving action and Sirovirechana Gana suggestive of Kapha Hara property

- It is mentioned under Pippalyadi Gana of Susrutha indicates prevention of Amotpatti and thereby preventing progression of Avarana Samprapti of $U d a-$ vartini. 


\section{CONCLUSION}

Now a days the gynaecological problems have increased than the earlier days, probably due to stressful $\&$ modern lifestyle, untimely \& unhealthy food habits which affect the uterine environment, and not following the proper regimens as mentioned in Ayurvedic classics

The aim of this study was to evaluate the effect of Panchapalaka Ghrita and Dhanyaka Ghrita in Udavartini Yoni Vyapad. Both Ghrita contains Tikta, Madhura and Katu Rasa, Ushna Virya, Madhura Vipaka and Vatanulomana properties that is found to be very effective in relieving the intensity, duration and site of pain and in associated complaints of irritability, headache, nausea, vomiting and diarrhoea.

The formulation contains drugs, which has Balya, Brimhana and Rasayana properties, hence helps in maintaining good health of the body and helps in enhances the immunity.

There was statistically significant improvement in all cardinal features of Udavartini/Primary dysmenorrhea On comparison between the groups, both groups showed significant improvement in the management of signs and symptoms of Udavartini Yonivyapad.

As in both the groups of Ghrita, have similar properties and action, Null Hypothesis is rejected and Alternate Hypothesis $\mathrm{H}_{1}$ - Both the Panchapalaka Ghrita and Dhanyaka Ghrita have significant effect in the management of Udavartini Yonivyapad is accepted.

\section{REFERENCES}

1. D C Dutta, Textbook of Gynaecology Including contraceptive, edited by Hiralal Konar, 7th edition, 2016, Jaypee brothers medical publishers (P) Ltd, New Delhi. Pg. No -146

2. D C Dutta, Textbook of Gynaecology Including contraceptive, edited by Hiralal Konar, 7th edition, 2016, Jaypee brothers medical publishers (P) Ltd, New Delhi. Pg. No -170

3. Sushruta, Dalhana Acharya, Sushruta Samhita with Nibandha Sangraha Commentary. $1^{\text {st }}$ edition, Varanasi. Chaukhambha Sanskrit Samsthan; 2010. Utthara tanta 38/9

4. Agnivesha, Charaka, Dridhabala, Chakrapani Dutta, Acharya J.T. Charaka Samhita with Ayurveda Dipika
Commentary. 1st ed. Varanasi. Chaukhambha Prakashan; 2009. Chikithsa sthana 30/115

5. Chakrapanidatta, Chakradatta Chikitsasangraha, English translation by Dr. G. Prabakar Rao, Chaukamba orientalia, Chowkhamba Sanskrit Series Office, Varanasi. First edition 2014, Sloka.no 60-61, Pg. no 315

6. Vangasena, Vangasena Samhita or Cikitsasara Samgraha, annoted by Pandit Hariprasad Tripadi, Chowkhamba Sanskrit Series Office, Varanasi, Vol.1, Edition: First, Year 2004, Sloka.no 114-115, Pg.no 188

7. Sushruta, Dalhana Acharya, Sushruta Samhita with Nibandhasangraha Commentary.1st ed. Varanasi. Chaukhambha Sanskrit Samsthan; 2010 Sutra. 45/16

\section{Source of Support: Nil Conflict of Interest: None Declared}

How to cite this URL: Sruthi K \& Kavitha B. K: A Comparative Clinical Study Of Panchapalaka Ghrita And Dhanyaka Ghrita In Udavartini Yonivyapad. International Ayurvedic Medical Journal \{online\} 2020 \{cited July, 2020\} Available from: http://www.iamj.in/posts/images/upload/2401 2407.pdf 